\section{Addressing the Factors Responsible for Schooling without Learning in Primary and Secondary Schools in Nigeria}

\author{
Yusuf Suleiman \\ Unicaf University, Cyprus \\ yusufsuleiman@gmail.com \\ https://orcid.org/0000-0002-4740-6839 \\ Yusuf Abiola Abubakar \\ Kwara State Universal Basic Education Board, Nigeria \\ yusufabiola50@gmail.com \\ Ibrahim Musa Akanbi \\ Kwara State Ministry of Tertiary Education, Science E Technology, Nigeria \\ musakaly@gmail.com
}

\author{
Addressing \\ the Factors \\ Responsible \\ for Schooling \\ without \\ Learning in \\ Primary and \\ Secondary \\ Schools in \\ Nigeria
}

\begin{abstract}
The most often debated topic among stakeholders in education and the generality of Nigerians today is the issue of decline in the quality of education at all levels (primary, secondary and tertiary institutions). To substantiate the foregoing debate, a new World Bank Report (2018) warns of learning crisis in Nigeria and other developing countries which face moral and economic problems because primary and secondary schools fail to equip students with the right education to succeed in life and that without learning, education would fail to deliver on its promise to eliminate extreme poverty and create shared opportunity and prosperity for all. Despite the establishment of Universal Basic Education (UBE) in 1999, which is saddled with the responsibility of ensuring the acquisition of the appropriate levels of literacy, manipulative and life skills as well as the ethical, moral and civic values needed for laying the foundation for lifelong learning for children, have continued to be a mirage. In view of the foregoing, this study examined the factors responsible for schooling without learning in primary and junior secondary schools. Those factors include insufficient budget allocation to education, lack of adequate infrastructure, lack of qualified teachers and poor remuneration package, and corruption. In addressing the aforementioned factors, this study used World Bank's (2018) solutions which have four steps. The first step is to find the truth from facts; the second step is to assess the learning so that it become a measurable goal; the third step is to make schools work for all children and the fourth step is to mobilize everyone who has stake in learning. In addition, recommendations were provided to ensure that the rising case of schooling without learning is eradicated.
\end{abstract}

Keywords - World Bank Report 2018, schooling without learning, primary and secondary schools, Nigeria

\section{Psynargia}

International Journal of Synergy and Research

Vol. 7, 2018

pp. $161-178$ 
IJSR 7

\section{Introduction}

Effective learning entails that students are able to comprehend and understand what has been taught in the classroom by their teachers. On the contrary, ineffective learning in school implies that students are not getting the right knowledge and skills which are necessary for them to succeed in life. Learning crisis is a moral and economic crisis, when delivered well, learning promises people work, improves earnings, healthiness, and a life without poverty. Good learning spurs innovation, fortifies institutions, and promotes social cohesion. But the forgoing benefits hinge on learning, and schooling without learning is a squandered opportunity. In addition, it is a great recognition that the children whose nations fail are the ones who are most in need of a sound education to prosper in life (Ajayi, 2007; Ejere, 2011; Makinde, 2010; Ololube et al., 2016; World Bank Report, 2018).

Warning of a learning crisis in global education, a new report by the World Bank (2018) indicates that schooling without learning is not just a misused development chance, but also great unfairness to children and young people in general. It is reported that without effective learning, education would fail to deliver on its promise to eradicate extreme poverty and generate shared opportunity and affluence for all. It is reported that after spending several years in school, millions of children cannot read, write or do basic math. According to the Bank, this learning catastrophe is spreading social gaps instead of tightening them. Those young students who are already deprived by conflict, poverty, disability or gender reach adulthood without even the most elementary life skills or talents. The foregoing statistics do not account for 260 million children who, for reasons of discrimination and other obstacles, are not enrolled in both primary and secondary school. While not all developing countries feel pain from such extreme learning gaps, many fall far short of stages they aspire to.

In India, in rural areas, almost three-quarters of third grade students were unable to solve a simple two-digit subtraction (such as "46-17") and by grade five, the majority of the students still could not do so. In Brazil, it is reported that at their present rate of improvement in education, it will not reach the rich-country average score in mathematics for 75 years, whereas achieving improvement in reading will take them 263 years. In Uganda, Kenya and Tanzania, their third-grade students were asked lately to read a sentence such as "The name of the dog is Puppy" in English or Kiswahili, surprisingly, three-quarters of the students failed to read it (World Bank Report, 2018).

In Nigeria, the regional synopsis on Education for All (EFA) report highlights the situation of education in Nigeria and concludes that the country is at serious risk of not achieving the universal basic education goal (Santcross et al., 2009; UNESCO-EFA Report, 2009). The report explains severe risk as moving away from the goal or progress. Sadly, with Education for all Development Index (EDI) of less than 0.8, Nigeria is among 16 countries in Sub-Saharan Africa that is very far from accomplishing EFA objectives (Ejere, 2011; The Nation Newspaper, 2008). Global competitiveness report for the period 2009-2010 indicates that Nigeria's basic education level was ranked $132^{\text {nd }}$ out of the 133 countries that were surveyed (Daily Sun Newspaper, 2009; Ejere, 2011). Similarly, the recent report from the World Bank revealed that Nigerian primary and secondary school children went to school without leaning. They opined that some of them finished schools without knowing anything. They warned that primary and secondary schools are failing 
to train students to prosper in life. And if this trend continues, it can be concluded that millions of young Nigerian students are faced with the prospect of lost opportunity and lower wages in later part of their lives (World Bank Report, 2018; Ololube et al., 2016).

In support of the above assertion, several studies have been conducted on the declining quality of education in Nigeria. For instance, a study conducted by Arong and Ogbadu (2010) on the drop in the quality of education in Nigeria from administrative perspective revealed that inadequate library facilities, lack of parental responsibilities, corruption, misplaced government priorities lack of qualified teachers, overpopulation, library facilities, are common in primary and secondary schools. In the same vein, Tayo and Talabi (2015) examined the teacher shortage in Nigerian schools. The outcome of their finding indicates that overpopulation of students, poor teacher's salary and working condition all culminating into job dissatisfaction were responsible for shortage of secondary school teachers. In view of the foregoing, this study addressed the factors responsible for schooling without learning in Nigeria, most especially in primary and secondary schools.

\section{An overview of national policy on education (primary and secondary) in Nigeria}

Education can be defined as the process of transferring culture, values, ethics and norms from one generation to another. It can also be defined as the process of cultural transformation and renewal. It is often said that education remains one of the tools for the transformation of an individual and society at large. It is recognized as one of the most powerful mechanisms for social modification, which plays a decisive role in nation-building (Ajayi, 2007; Edho, 2009; Ololube, 2016). Makinde (2010) opined that education is equally seen as a way of developing intellectual and functional capabilities of people. That is why education is placed on high premium in Nigeria's education policy. The structure of Nigerian education is structured into four categories, they are early child care and development; basic education; post-basic education; and tertiary education. Table 1 shows a comprehensive structure of Nigerian education system as contained in the policy.

\begin{tabular}{ll}
\hline 1. Early Child Care and Development & Aged $0-4$ years \\
\hline 2. Basic Education & $\begin{array}{l}\text { Aged } 5-15 \text { years (it comprises pre-primary 1 year, 6 years of primary education and } \\
\text { 3 years of junior secondary education) }\end{array}$ \\
\hline 3. Post-Basic Education & 3 years in senior secondary school and technical colleges \\
\hline 4. Tertiary Education & Provided in colleges of education, monotechnics, polytechnics, and universities \\
\hline
\end{tabular}

Source: Federal Republic of Nigeria (2013).

As encapsulated in National Policy on Education, Section 1 articulates the procedures, objectives, standards, structures, strategies, and administration for accomplishing the national education goals in Nigeria. The general philosophy of the nation includes, but is not restricted to:

a. living in unity and harmony as one indivisible, indissoluble, democratic and sovereign nation founded on the principals of freedom, equality and justice; and

\author{
Addressing \\ the Factors \\ Responsible \\ for Schooling \\ without \\ Learning in \\ Primary and \\ Secondary \\ Schools in \\ Nigeria
}


IJSR 7

b. promoting inter-African solidarity and world peace via understanding.

Also, Nigeria's philosophy of education is built on the following set of beliefs:

a. education is an instrument for national development and social change;

b. education is vital for the promotion of a progressive and united Nigeria;

c. education maximizes the creative potentials and skills of the individual for selffulfillment and general development of the society;

d. education is compulsory and a right of every Nigerian irrespective of social status, gender, color, ethnic background, religion and any peculiar individual challenges; and

e. education is to be qualitative, comprehensive, functional and relevant to the needs of the society.

The five main goals of education in Nigeria are:

a. development of the individual into a morally sound, patriotic and effective citizen;

b. total integration of the individual into the immediate community, the Nigerian society and the world;

c. provision of equal access to qualitative educational opportunities for all citizens at all levels of education, within and outside the formal school system;

d. inculcation of national consciousness, values and national unity; and

e. development of appropriate skills, mental, physical and social abilities and competencies to power the individual to live in and contribute positively to the society.

The policy states the following as the specific goals of education in Nigeria:

a. to ensure and sustain unfettered access and equity to education for the total development of the individual;

b. to ensure the quality of education delivery at all levels;

c. to promote functional education for skill acquisition, job creation and poverty reduction;

d. to ensure periodic review, effectiveness and relevance of the curriculum at all levels to meet the needs of the society and the world of work;

e. to collaborate with development partners, the private sector, non-governmental organizations and local communities to support and fund education; and

f. to promote information technology capability at all levels (Federal Republic of Nigeria, 2013).

\section{Aims and objectives of basic (primary \& junior secondary) education in Nigeria}

\section{Primary Education}

Primary Education is the education given to children aged 6-12 years (Section 2c). However, Section 2, Sub-section 19 states the objectives of primary education in Nigeria as follows:

a. to inculcate permanent literacy, numeracy and the ability to communicate effectively;

b. to lay a sound basis for scientific, critical and reflective thinking; 
c. to promote patriotism, understanding, unity and fairness;

d. to instill social values and moral norms in the child;

e. to develop in the child the ability to adapt to the changing environment; and

f. to provide opportunities for the child to develop life manipulative skills (Federal Republic of Nigeria, 2013).

\section{Junior Secondary Education}

Section 2, Sub-section 21 of the policy defined Junior Secondary Education as the type of education which a child receives immediately after primary education. Also, Section 2, Sub-section 22 stipulates the objectives of Junior Secondary Education as follows:

a. to provide the child with diverse basic knowledge and skills for entrepreneurship and educational innovation;

b. to develop patriotic young people equipped so as to contribute to social development and the performance of their civic responsibilities;

c. to inculcate values and raise morally upright individuals capable of independent thinking, and who appreciate the dignity of labor; and

d. to inspire national consciousness and harmonious co-existence irrespective of differences in religion, endowment ethnic, socio-economic background and color (Federal Republic of Nigeria, 2013).

\section{Objectives of post-basic ( senior secondary) education}

Section 3, Sub-section 33 defined Post-Basic Education as the education that children receive after successful completion of basic education. Specifically, Section 3, Subsection 36 states the following as the objectives of Post-Basic Education in Nigeria:

a. to provide holders of Basic Education Certificate with opportunity for education of a higher level, irrespective of social status, gender, ethnic background or religious;

b. to offer diversified curriculum to cater for the differences in disposition, future roles and opportunities;

c. to provide trained manpower in the applied sciences, technology and commerce;

d. to provide entrepreneurial, technical and vocational job-specific skills for selfreliance;

e. to develop and promote Nigerian languages, art and culture in the context of world's cultural heritage;

f. to inspire students with a desire for self-improvement;

g. to foster patriotism, national unity and security education;

h. to raise morally upright and well-adjusted individuals who can think independently and rationally, respect the views and feelings of others and appreciate the dignity of labor (Federal Republic of Nigeria, 2013).

Taken together, the policy states that in order to realize the above objectives of basic and post-basic education and gain from its contribution to the national economy, the government shall take necessary measures to ensure that: 
IJSR 7 a. educational activities shall be learner-centered for maximum development and self-development and self-fulfillment;

b. teaching shall be practical, activity-based, experiential and IT supported;

c. education shall be related to overall community needs;

d. all tiers of government shall be promote the establishment and support of reading clubs in schools, community libraries and other resources that will enhance learning;

e. continuing education shall be part and parcel of the education system; and

f. every child shall be taught in the mother tongue or language of the immediate community for the first four years of basic education. In addition, it is expected that every child shall learn one Nigerian language (Federal Republic of Nigeria, 2013).

\section{Schooling without learning in Nigeria: Evidence from the World Bank Report (2018)}

In spite of the laudable policy of education in Nigeria, evidence revealed that there is a serious learning crisis. The World Bank Report (2018) confirmed there is a crisis in learning in Sub-Saharan countries (including Nigeria). They opined that the quality and quantity of education vary generally within and across countries and that hundreds of millions of children around are growing up without even the most basic life skills. Their reports hinged on three messages which conclude that schooling is not the same as learning; that schooling without learning is not just a wasted opportunity, but a great injustice and lastly, there is nothing inevitable about low learning in low- and middleincome countries. The schooling without learning has three main dimensions:

1. The first dimension of the crisis is the poor learning outcomes themselves: children unable to comprehend and understand what has been taught in the classrooms by teachers.

2. The second dimension of the learning crisis is its immediate causes: children arrive unprepared to learn, teachers often lack the skills or motivation to teach effectively, inputs often fail to reach classrooms or to affect learning, and poor management and governance often undermine the schooling quality.

3. The third dimension of the crisis is its deeper systemic causes: it has become a systemic thing to have children leaving schools without learning anything (unable to read and write effectively).

Furthermore, using the recently updated global data set on education quality, the Bank Report revealed that decline in school completion, low proficiency in mathematics and reading, and teachers' absence in schools are contemporary issues in secondary schools in Sub-Saharan African countries. They are explained below (Figure 1): 
Pobrane z czasopisma International Journal of Synergy and Research http://ijsr.journals.umcs.pl Data: 26/04/2023 11:14:47

Decline in school completion

\section{Only 1 in 3 children complete secondary school in low and middle-income countries}

\section{Secondary School Completion Rates Vary Greatly by Region}

Upper secondary school comple:
Eastern Europe \& Central Asia
East Asia \& Pacific
Middle East \& North Atrica
Latin America \& Caribbean
South Asia
Sub-Saharan Africa

Source: World Bank Report (2018).
Addressing the Factors

Responsible for Schooling without Learning in Primary and Secondary Schools in Nigeria

Figure 1.

Decline in school completion in lowand middle-income countries

Figure 1 indicates that only 1 in 3 children complete secondary school in low- and middle-income countries, including Nigeria. For instance, the figure revealed that in lowand middle-income countries, out of every 100 students entering primary education, 90 complete their primary education, 61 complete lower secondary education, and just 35 complete upper secondary education. The foregoing data implies that about a third of children leave school between lower and upper secondary, many of whom are unprepared for more education.

\section{Mathematics and reading proficiency issue}

\section{In the poorest countries, fewer than $\mathbf{1}$ in $\mathbf{5}$ primary school kids are proficient in math \& reading}

\section{Where are Primary School Students Passing Learning Assessments?}

Average percentage of students assessed proficient in math 8 reading assessments by income group and region

Mathematics

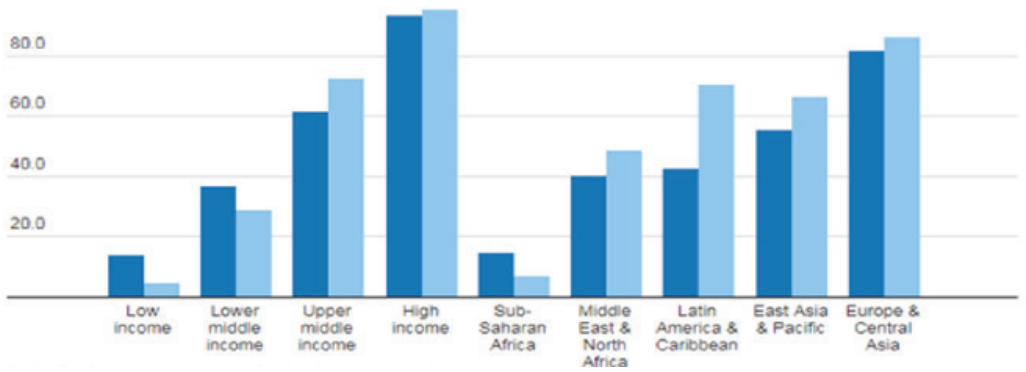

Fiĝure 2.

Mathematics and reading proficiency issue

Source: World Bank Report (2018) 


\section{IJSR}

7

Figure 3.

Teachers' absence from classrooms
Mathematics and reading proficiency issue is another issue raised by the Bank Report which calls for urgent attention. As displayed in Figure 2, the World Bank Report (2018) revealed that in the poorest countries, fewer than 1 in 5 primary school kids are proficient in mathematics and reading, meaning that it is not just the quantity or magnitude of education that matters, it is the quality. And that it is difficult to measure learning in a way that is similar across countries, but the foregoing draws on new studies which attempt to do just that. Furthermore, the Report states that more than $60 \%$ of primary school children in low- and middle- income countries fail to accomplish a minimum benchmark proficiency in mathematics and reading. By comparison, in high-income countries, approximately all children attain this level in primary school.

Teachers' absence from classrooms

\section{In Africa, Teachers are Often Absent from Classrooms and School}

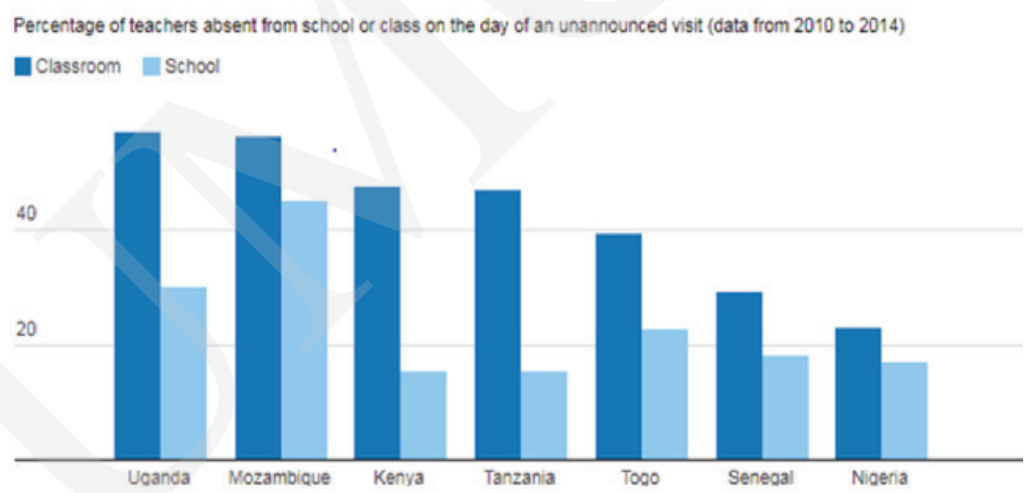

Source: World Bank Report (2018).

Figure 3 indicates that in Africa, teachers are often absent from classrooms and school. Across seven African countries, an average of one in five teachers was absent from school on the day of an unannounced visit by survey teams, and two in five were absent from their classrooms even though they were at school. In remote communities, these problems are even more severe. Specifically, in Uganda, 60\% were absent from classrooms while $30 \%$ did not come to school at all. In Mozambique, over $60 \%$ of teachers failed to show up in classroom to teach students and $40 \%$ were absent from school. Sadly, in Kenya, it shows that $50 \%$ of teachers failed to show up in the classrooms while $30 \%$ did not come to school at all. Similarly, over 50\% teachers in Tanzania failed to show up in classroom while $30 \%$ of them were totally absent from school. In Togo, $50 \%$ of their teachers do not attend classroom while $35 \%$ did not visit school at all. Also, $25 \%$ of their teachers were absent from classrooms, while $18 \%$ failed to show up in school. Lastly, $20 \%$ of teachers boycotted classrooms, while $18 \%$ failed to show up in school. In view of the foregoing, it can be deduced that it is not just students who are failing in schools, schools are also failing their students and that this kind of analysis is not intended to blame teachers, but to call attention to systematic issues of resourcing, management and governance which often undermine the quality of teaching. 


\section{Major factors responsible for schooling without learning in Nigeria}

\section{Insufficient budget allocation}

Insufficient budget allocation to the education sector is one of the factors responsible for schooling without learning in Nigeria. Even though the Nigerian government has continued to reiterate its commitment to the development of the education sector, Nigeria's education sector has received much lower than $26 \%$ of national budget, as recommended by the United Nations Educational Scientific and Cultural Organization (UNESCO) so as to enable the nations to adequately cater for rising education demands (Ejere, 2011; Famurewa, 2014; Ibara, 2011; Ololube, 2016; Tiamiyu, 2012). Sadly, the Nigerian government has been consistently underfunding the sector. Although the Second National Development Plan (1970-1974) raised the education budget to $13.5 \%$, it fell to $7.5 \%$ in the Third National Development Plan (1975-1980). Although it rose again to $17.3 \%$ in the Fourth National Development Plan (1981-1985), it has not been higher than $13.5 \%$ since 1990 except for the year 1997 when education was given $17.5 \%$. From 2008 to 2018 , the trend in the budget allocation by the federal government to education has shown marginal yearly increases, however, except for the years 2017 and 2018 which saw a decrease in the allocations for the preceding years. Specifically, in the 2018 budget proposal presented by President Muhammadu Buhari, 7\% of the budget was allocated to education (Daily Post, 2017). In addition, a comparative analysis of budget allocations by other countries in Africa indicated that the government is yet to allocate the needed money to education (Ololube, 2016). Table 2 and Figure 4 show the budget allocation to education in Nigeria from 2008 to 2018. Also, Figure 5 juxtaposes the analysis of Nigeria's budget allocation to education with other selected African countries.

\begin{tabular}{lc}
\hline \multicolumn{1}{c}{ Fiscal year } & Budget allocation to education in Nigeria (2008-2018) \\
\hline 2008 & $13 \%$ \\
\hline 2009 & $8 \%$ \\
\hline 2010 & $6 \%$ \\
\hline 2011 & $8 \%$ \\
\hline 2012 & $10 \%$ \\
\hline 2013 & $8 \%$ \\
\hline 2014 & $10 \%$ \\
\hline 2015 & $9 \%$ \\
\hline 2016 & $8 \%$ \\
\hline 2017 & $6 \%$ \\
\hline 2018 & $7 \%$ \\
\hline
\end{tabular}

Source: Ololube (2016); Premium Times (2017); Daily Post (2017).
Addressing the Factors Responsible for Schooling without Learning in Primary and Secondary Schools in Nigeria
Table 2. Budget allocation to education in Nigeria 
Pobrane z czasopisma International Journal of Synergy and Research http://ijsr.journals.umcs.pl Data: 26/04/2023 11:14:47

\section{IJSR}

7

Figure 4.

Trend of budget allocation to education in Nigeria (2008-2018)

\section{Figure 5.}

A comparative representation of countries' yearly expenditures on education from 2012-2016

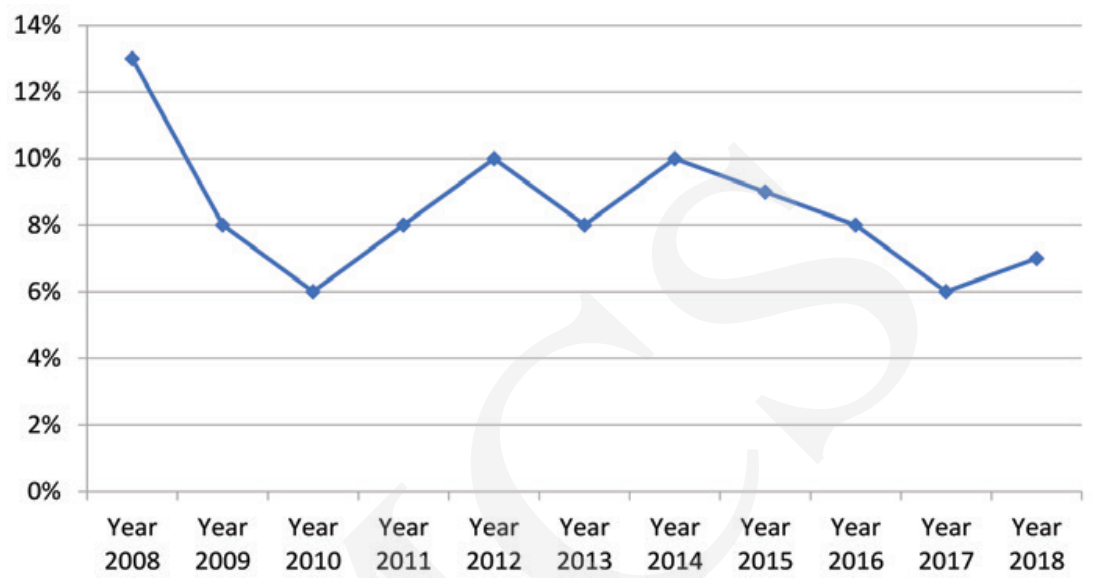

Source: Ololube (2016); Premium Times (2017); Daily Post (2017).

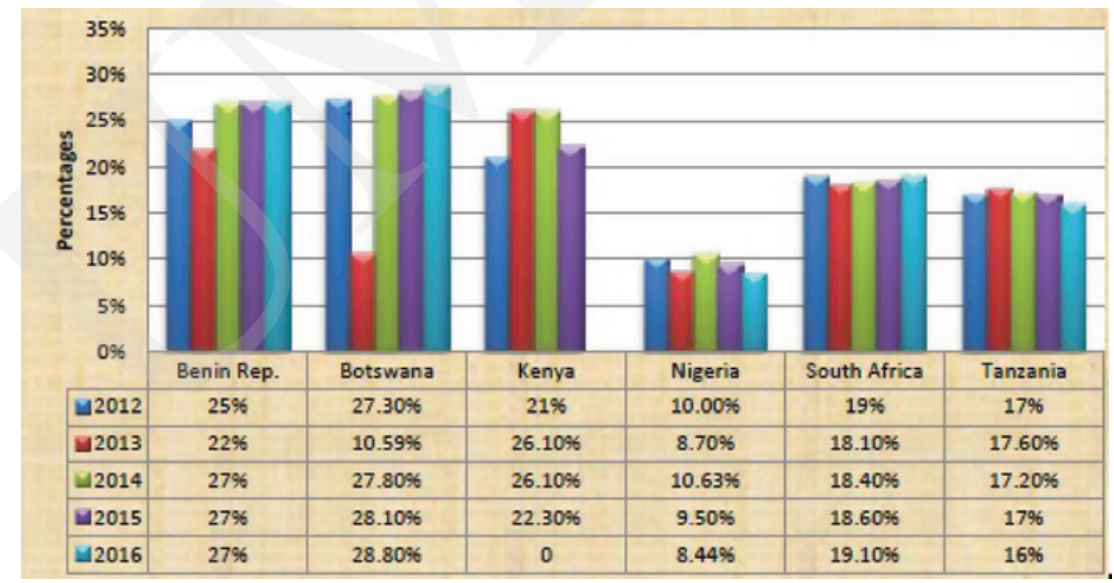

Source: Ololube (2016).

\section{Lack of adequate infrastructure}

A survey carried out by Adepoju and Fabiyi (2007) on existing situation of primary schools in Nigeria revealed a disheartening statistics that $87 \%$ of classrooms are overcrowded, $12 \%$ of pupils sit on the floor, $77 \%$ of pupils lack text books, while $38 \%$ of classrooms have no ceilings. Also, Omokhodion's (2008) study indicated that the shortage of infrastructure; textbooks, materials and equipment are obstructing the successful implementation of the Universal Basic Education (UBE) programme in Nigeria. Lack of infrastructure (e.g. classroom, laboratories, libraries and other facilities) is one of the problems affecting the development of education in Nigeria. Sadly, primary and secondary school buildings are nothing to write home about, most especially in rural areas. Those with classrooms do not have enough furniture for a proper school setting, 
and this make student to sit on the floor. In some cases, few schools with laboratories and workshops have lost almost all the equipment, those that exist are not serviceable while majority of schools do not have laboratories and workshops at all. Library is seen as is an important unit which helps to promote the growth of knowledge and center of learning. If the library is well organized and used, it helps schools to achieve its objectives as stated in Nigeria's policy of education. But what we have today in most schools can be called archivist's collection and not library because books are not available and even if they are, they are out of students' reach (Acho and Abuh, 2016; Agabi, 2014; Ejere, 2011; Ekankumo and Kemebaradikumo, 2014; Onyeike and Owuama, 2012). Taken together, it can be said that lack of or inadequate availability of infrastructure is among the factors that contribute to the falling quality of education in Nigeria.

\section{Shortage/lack of qualified teachers and poor remuneration package}

Firstly, on shortage of teachers, research indicates that the total number of teachers available in secondary schools in Nigeria is far below required for effective implementation of curriculum content. Specifically, UNESCO's report shows that the total number of teachers available in Nigeria in 2009 was 466,800 and that in 2015, 688,200 teachers were needed. This demonstrates that Nigeria needs to increase the number of its teaching employees by $6.68 \%$ yearly to meet the teachers demand as recommended by UNESCO (The Guardian, 2014). In support of the foregoing, Makinde (2010) and Tayo and Talabi (2015) opined that the quality of education in Nigeria will continue to fall due to shortage of teaching staff. Secondly, on quality of teachers recruited in secondary schools in Nigeria, Arong and Ogbadu (2010) observed that teachers are those who are trained and equipped professionally to guide the act of teaching in the classroom. So, when teachers are not well-equipped and lack the quality wherewithal of instruction that is expected of them, what they give to pupils/students they teach will be will be of worse quality and the outcome of such learning will be half-baked and of low value. Tayo and Talabi (2009) and Tayo (2013) affirmed that at the primary and secondary levels of education in Nigeria, teachers do little or no teaching in classroom and thus no quality knowledge is delivered. He explains that a teacher who has no knowledge to teach will transmit nothing meaningful to his/her students. In addition, using observation method, a visit to some public and private primary schools in some states revealed that majority of schools domiciled in rural areas are short of teachers to teach children. Quality of teachers is also a great concern that needs urgent attention if we have desire to improve the quality of education in Nigeria. Similarly, many teachers in the rural areas often seek transfer into the schools that are domiciled in the city. Thirdly, poor remuneration package is also one of the factors that contribute to schooling without learning in Nigerian schools. Teachers in primary and secondary schools are poorly remunerated. Their rewards are never forth-coming; some of them collect reduced salaries while some are denied. Promotion and training of teachers is only a figment of imagination and it is always subjected to political horse riders. No matter how articulate Nigeria's curriculum may be, the poor motivation of teachers will continue to have adverse effect on standard of education (Adeyemi, 2011; Ololube et al., 2016).

\author{
Addressing \\ the Factors \\ Responsible \\ for Schooling \\ without \\ Learning in \\ Primary and \\ Secondary \\ Schools in \\ Nigeria
}


IJSR 7

\section{Corruption}

Corruption is seen as the cankerworm that is affecting the growth of Nigeria. In fact, some believe that corruption has been institutionalized due to the various disheartening revelations on corruption involving officials. In the education sector, corruption is one of the major factors that contributed to the vanishing quality of education. In some urban and rural area schools, it is easy to note that some stakeholders (including school supervisors, school principals or head teachers, school teaching and non-teaching staff) involve in one or two forms of dishonest behavior that dampens the growth of education. A visit to some of the public and private schools revealed some acts of dishonesty in the areas of over enrollment of pupils and students into primary and junior secondary schools through kickbacks. In the same vein, embezzlement and misappropriation of funds that is meant for school development projects by government agencies is a common knowledge in Nigeria. It is obvious that not all funds allotted for the UBE programme are used for the planned purposes due to high level of fraud in key implementing agencies and uneconomical spending (Ajayi, 2007; Edho, 2009; Egonmwan, 2002; Ejere, 2011; Ololube, 2016; SERAP, 2013; World Bank Report, 2008). According to Arong and Ogbadu (2010), recruitment and posting of teachers to schools has some corruption elements. Additionally, absenteeism in schools and work place and the existence of ghost workers in state SUBEBs (State Universal Basic Education Boards) are all a disservice to the advancement of education system in Nigeria. As for school inspectors and supervisors, the story of lack of integrity is the same. Some deceitful schools inspectors at all levels (federal, state and local governments) merely get to the principals/head teachers' office, where he/she is offered a bribe and go back without really inspecting the schools.

\section{Addressing schooling without learning in Nigeria using the World Bank (2018) recommendations}

The World Bank Report (2018) admits that, when countries of the world and their leaders make "education for all" a big priority, then schooling standards can improve dramatically. For instance, from a war-torn country with very low literacy rates in the 1950s, South Korea succeeded in achieving a complete children enrollment by 1995 using high-quality education through its secondary schools. Interestingly, its children performed excellently well at the top levels on global learning assessments. In the same vein, Vietnam's 2012 results from an OECD test for high school students in science, reading, and math, indicated that its children excelled at the equal level as those in Germany, even though Vietnam is a much poorer country. Similarly, Peru achieved some of the fastest growth in overall learning outcomes due to the government's rigorous policy action education. In countries such as Liberia, Papua New Guinea, and Tonga early grade reading among children improved significantly within a very short time, this is due to dedicated determinations based on evidence.

Relying on evidence and information gathered during extensive consultations in more than 20 countries, with development and research organizations, governments, civil society organizations (CSOs), and the private sector, the World Bank Report (2018) suggests four key policy recommendations that the Nigerian government can 
use to address schooling without learning in Nigeria, so that the country's education at primary and secondary school levels can improve significantly. Specifically, the report recommends real policy steps to help resolve this awful learning crisis in the areas of learning assessments, using proof of what works and what does not to guide education policy making; and marshaling a strong social measure to drive for education reforms that implement the "learning for all" approach. Figure 6 explains how the four key recommendations can be used to address schooling without learning in Nigeria.

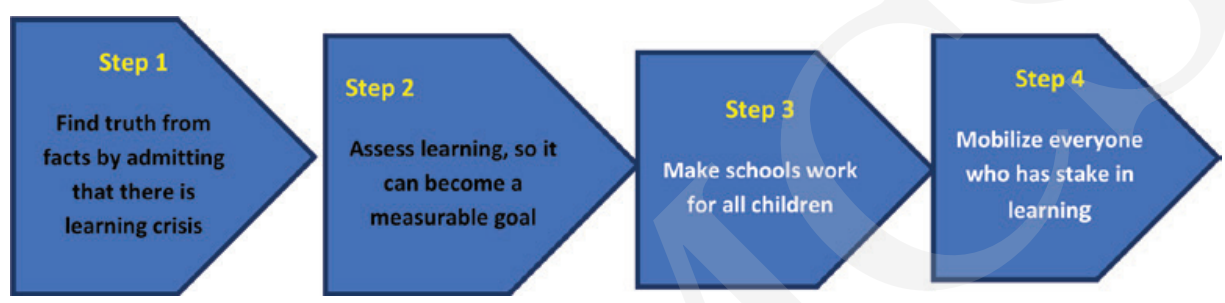

Source: World Bank Report (2018).

\section{Step one: Find the truth from facts}

The only way to make reasonable progress in addressing schooling without learning is to "find truth from facts" as contained in the global report which cut across all continents and its countries. The realities about education expose a painful truth. For too many children, schooling does not mean learning. Having in mind that there is a learning crisis, government at all levels (local, state and federal) must identify what drives these learning shortfalls, not only the ways in which teaching and learning breaks down in many schools, but also the deeper political forces that cause these problems in education to persist.

\section{Step two: Assess learning, so it can become a measurable goal}

After finding the truth from facts, the next step is to assess learning so that it can become a measurable goal. Evidence from the bank indicates that only half of all developing countries have metrics to measure learning at the end of primary and secondary school. Therefore, a well-designed student assessment can help teachers to guide students, develop system management, and focus people's attention on learning. The foregoing measures can edify national policy choices, track improvement, and shine a focus on children who are being left behind in education.

\section{Step three: Make schools work for all children}

After assessing learning so that it can become a measurable goal, the next step is to make schools in Nigeria work for all children irrespective of their religion, culture, ethnic, status, creed, gender and other affiliations. In achieving this, modern classrooms should be built for children, and it is equally important for the government to level the playing field by decreasing stunting and supporting brain development through early and proper nourishment and encouragement so that children can be in the right frame of mind and ready to learn. In the same vein, qualified and adequate teaching and non-

\author{
Addressing \\ the Factors \\ Responsible \\ for Schooling \\ without \\ Learning in \\ Primary and \\ Secondary \\ Schools in \\ Nigeria
}

Figure 6.

Four key policies that can be used to address

schooling without learning in Nigeria as suggested by the World

Bank Report (2018) 
IJSR 7 teaching staff should be recruited in schools (rural and urban areas). They should also be motivated by tailoring training that is reinforced by mentors. The deployment of adequate technologies (computers, printers, satellite television, generator, e-library, projector, tablets, etc.) that can help teachers in their work with children, and strengthen school management, including principals that are needed in schools. Meeting of the foregoing mentioned needs will stimulate effective teaching and learning in classroom and make children to embrace learning.

\section{Step four: Mobilize everyone who has stake in learning}

After making schools work for children, the last step is to mobilize everyone who has stake in learning to ensure that education is given topmost attention. To be precise, information and metrics should be used to mobilize citizens, increase accountability, and create political will for nation's education reform. Constant involvement of stakeholders (e.g. parents'/teachers' association, traditional rulers, philanthropists, principals and vice-principals, teachers, ministry of education, educational administrators, policy makers, non-governmental organizations (NGOs), etc.) in education, including the business community, in all stages of education reform, from design to implementation, should be provided. The foregoing is sacrosanct according to the World Bank, because research shows that developing countries are lagging behind educationally. They are far from where they should be on learning because many do not invest adequate financial resources and most need to invest more efficiently. But, it is not only a matter of money, there is also a need to invest more in the capacity of the people and organizations tasked with teaching children. Education transformation is urgently needed and requires resolution as well as the political configuration of government, entrepreneurs, media, teachers, parents, and students. They all have to value and demand for improved learning in schools.

\section{Conclusions and recommendations}

Unarguably, education remains the wheel of nation's development and it is the foundation upon which all other segments are built. If the foundation is faulty, there is nothing that righteous can do. Undoubtedly, the structure of education in Nigeria has been deeply affected, and only the fragments are left. If the foundation of the Nigeria's education is feeble and if nothing is done to salvage it, we will continue to have not only disparaging statistics of schooling without learning (as reported by the World Bank in 2018), but also it can be concluded that the hope of our unborn children cannot be assured. In addition to the recommendation provided by the World Bank, this study suggests the use of Ejere's (2011) six effective strategies that can be used to address the rot in primary and secondary schools in Nigeria. They are: good infrastructure, improved human resource, better financial resources, adequate data gathering, and social mobilization and enforcement.

\section{Good infrastructure}

To improve the learning setting, huge government investment in school (primary and secondary) infrastructure developments is needed. Every school should be provided 
with adequate modern facilities like classrooms, libraries, laboratories, computer center, portable water, a well-equipped clinic, toilets, electricity, and furniture. Also, adequate teaching and learning should be provided. Private schools' owners should be mandated to improve infrastructure in their respected schools.

\section{Improved human resources}

There is no doubt that if we want to raise the standard of education in Nigeria, the recruitment of adequate and qualified teachers are needed. Additionally, training and retraining of teachers in the right quantity and quality is sacrosanct. Also, efforts should be increased with regard to retaining and continuous professional development of teachers through capacity building programmes such as workshops and seminars in order to unceasingly update their professional knowledge and skills to ensure effective actualization of the Universal Basic Education (UBE) objectives. In order to mitigate the problem of lack of qualified teachers, especially in rural schools, the multi-grade teaching concept should be embraced. The concept of multi-grade teaching refers to a situation where pupils of different ages, grades and abilities are taught in the same classroom simultaneously (Gabriel, 2008). This teaching approach will be particularly relevant amongst nomadic pastoralists, migrant fisher folks and farmers as these groups already suffer from existing inequalities in education. Moreover, through the assistance of Teachers' Registration Council of Nigeria (TRC), there should be annual improvement in the percentage of professionally qualified teachers until $100 \%$ is achieved. In addition, apart from the teaching staff, the capacity of all personnel of UBE implementing agencies, such as Local Government Education Authorities (LGEAs); and even members of School Based Management Committees (SBMCs) must be improved. As such, they should also benefit from training and capacity building so as to make them alive to their responsibilities.

\section{Better funding}

It is no news that budget allocation to the education sector in Nigeria is worrisome, it can be concluded that Nigeria is yet to implement UNESCO's recommendation, which recommend countries to allocate $30 \%$ of their budget to education. In order to get it right in primary and junior secondary schools in Nigeria, UBE needs to benefit from sustainable funding. Since all the three tiers of government (federal state and local governments) have concurrent responsibilities for education provision in the country, thus financial resources for implementing UBE programmes should be sufficiently provided for in their annual budgetary allocations. In the same vein, the government at all levels should increase the funding of education by legislating the approval of minimum allocation of at least $30 \%$ to education, and approved funds should be constantly released to implementing agencies without interruptions. In order to access the UBE intervention fund that is usually made available yearly, states should endeavor to promptly fulfill their counterpart obligations. Specifically, states accused of failure to forward their counterpart funds should be severely sanctioned so as to serve as deterrent to other states who might want to indulge in a similar act. Furthermore, international development partners (such as the World Bank, UNESCO, USAID,

\author{
Addressing \\ the Factors \\ Responsible \\ for Schooling \\ without \\ Learning in \\ Primary and \\ Secondary \\ Schools in \\ Nigeria
}


IJSR 7
USAID and UNICEF, NGOs) and communities should increase their contribution to the development of basic education in Nigeria, so as to complement the efforts of the various tiers of government by not only meeting their financial pledges but also increasing their financial support. Lastly, to make sure that the society gets value for money being invested in basic education, there should be emphasis on real results in regard to expenditure tracking. Strict adherence to due process, procurement procedures as well as the provisions of the Fiscal Responsibility Act (2007) will help bring about transparent and accountable financial management, thereby checking corruption and improper diversion of UBE funds. Finally, anti-corruption agencies such as Independent Corrupt Practices Commission (ICPC), Economic and Financial Crimes Commission (EFCC), Code of Conduct Bureau (CCB) and Code of Conduct Tribunal (CCT) should endeavor to monitor thoroughly the disbursement and application of UBE funds at all levels of government.

\section{Quality assurance}

Quality assurance is an effective mechanism which can be used to ensure effectiveness in education. To achieve the foregoing, quality assurance office at the level of federal, state and local governments should do more on monitoring and proper assessment should be conducted on a regular basis at the various stages of the UBE programme. Similarly, more attention should be paid to school evaluation, inspection and monitoring as a quality control policy to check the quality of delivery of the UBE programme. Comprehensive and regular monitoring and supervision will tell early whether programme aims are being met or not. Lastly, schools' head teachers and principals should also be ready to effectively supervise their teaching and non-teaching staff to guarantee the quality of delivery of the UBE curriculum.

\section{Adequate data gathering}

Lack of adequate data is the bane of education in Nigeria. Without accurate and reliable data, no important planning can be made and it will be problematic to education policy at planning and implementation stage. In light of the foregoing, all UBE operators (governmental and non-governmental) should constrain themselves to the collection of appropriate, correct and reliable data. Likewise, all principals and head teachers and their teaching staff should ensure that basic records are collected and maintained at all times. The recognition and use of functional Education Management Information System (EMIS) at all levels of government is a needed measure for education development in Nigeria.

\section{Social mobilization and enforcement}

Indeed, efforts should be made to ensure sustained community participation and ownership of basic education. As such, public enlightenment and social mobilization should be a constant process in UBE implementation so as to stimulate full participation by all segments of the Nigerian society, most especially at the community level. Appropriate legal sanctions as recommended by the UBE Act (2004) should be enforced on parents/guardians who refuse to send their children/wards to school. However, the application of sanctions can only be realistic if the UBE is indeed free. For example, 
hidden costs should be eliminated by providing uniforms, books and other learning materials to the pupils or students free of charge. To increase the level of awareness of the populace, it is also suggested that the UBE Act should be translated into the three major Nigerian languages - Hausa, Igbo and Yoruba. In addition, to further promote universality and equity in access to basic education, more special schools should be established to cater for the physically challenged and children with special needs. Lastly, nomadic, Quranic (Almajiri) and adult literacy programmes should be fully integrated into UBE programmes.

\section{References}

Acho, Y., and Abuh, P.A. (2016), "Corruption and accountability in the Nigerian public sector: An empirical discourse", International Journal of Public Administration and Management Research, vol. 3, no. 3, pp. 47-54.

Adepoju, A., and Fabiyi, A. (2007), Universal Basic Education in Nigeria: Challenges and Prospects, available at: http://uaps.2007.prineeton.edu

Adeyemi, T.O. (2011), "The demand and supply of qualified teaching manpower in secondary schools in Ekiti State, Nigeria", Journal of Social Sciences, vol. 3, no. 4, pp. 281-282.

Agabi, C.O. (2014), Teaching and Resources Management in Education, Rodi, Port Harcourt.

Ajayi, I.A. (2007), "Achieving universal basic education (UBE) in Nigeria: Strategies for improved funding and cost effectiveness", The Social Sciences, vol. 2, no. 3, pp. 342-345.

Arong, F.F., and Ogbadu, M.A. (2010), "Major causes of declining quality of education in Nigeria from administrative perspective: A case study of Dekina Local Government Area, Kogi State", Canadian Social Science, vol. 6, no. 3, pp. 183-198.

Daily Post (2017), 2018 Budget: Buhari under fire over 7 percent allocation to education, available at: http://dailypost.ng/2017/11/08/2018-budget-buhari-fire-7-percent-allocation-education/ (accessed: 27 March 2018).

Daily Sun (2009), Global Competitiveness Report, October 12, p. 16.

Edho, O.G. (2009), "The challenges affecting the implementation of the universal basic education (UBE) in Delta State, Nigeria", Journal of Social Sciences, vol. 20, no. 3, pp. 183-187.

Egonmwan, J. (2002), Public Policy Analysis: Concepts and Applications, S.M.O. Aka and Brothers Press, Benin City.

Ejere, E.I. (2011), "An examination of critical problems associated with the implementation of the Universal Basic Education (UBE) Programme in Nigeria”, International Education Studies, vol. 4, no. 1, pp. 221-229.

Ekankumo, B., and Kemebaradikumo, N. (2014), "Quality financing of higher education in Nigeria: A nostrum for the provision of quality education", Journal of Education and Practice, vol. 5, no. 19 , pp. $78-90$.

Famurewa, I.O. (2014), "Inadequate funding as the bane of tertiary education in Nigeria", Greener Journal of Economics and Accountancy, vol. 3, no. 2, pp. 020-025.

Federal Republic of Nigeria (FRN) (2013), National Policy on Education, Nigeria: NERDC, Lagos. Gabriel, A.O. (2008), Multi Grade Teaching: Implications for the Universal Basic Education in Nigeria, UBEC, Abuja.

https://reliefweb.int/report/world/worlddevelopment-report-2018-learning-realize-education-spromise (accessed: 27 March 2018).

http://informationparlour.com/article-education-falling-standard-education-nigeria (accessed: 27 March 2018).

Ibara, E.G. (2011), "Funding higher education in a dwindling fiscal resources allocation: The Nigerian perspective", Journal of Sustainable Development in Africa, vol. 13, no. 3, pp. 1-9.

\author{
Addressing \\ the Factors \\ Responsible \\ for Schooling \\ without \\ Learning in \\ Primary and \\ Secondary \\ Schools in \\ Nigeria
}


IJSR 7
Makinde, M.A. (2010), Effective Management of Secondary Schools: A Teacher-Inspector's Perspective, Mosmak Enterprise, Ibadan.

Nation Newspaper (2008), Education for All (EFA), October 16, pp. 17-32.

Ololube, M.P. (2016), "Education fund misappropriation, mismanagement and the provision of quality higher education in Nigeria", International Journal of Scientific Research in Education, vol. 9, no. 4, pp. 333-349.

Ololube, N.P., Onyekwere, L.A., and Agbor, C.N. (2016), "Effectively managing inclusive and equitable quality education to promote lifelong learning opportunities (LLO) for all”, Journal of Global Research in Education and Social Science, vol. 8, no. 4, pp. 179-195.

Omokhodion, J. (2008), "Assessing the preparedness of Nigeria for her universal basic education program", Pakistan Journal of Social Science, vol. 5, no. 9, pp. 866-870.

Onyeike, V.C., and Owuama, D.N. (2012), "Constraints in planning and implementation of higher education programmes in Rivers Nigeria”, European Scientific Journal, vol. 8, no. 4, pp. $86-100$.

Premium Times (2017), 2017 Budget: Again, Nigeria fails to meet UN benchmark on education, available at: https://www.premiumtimesng.com/news/top-news/218097-2017-budget-nigeriafails-meet-un-benchmark-education.html (accessed: 27 March 2018).

Santcross, N., Hinchliffe, K., Williams, A., and Onibon, F. (2009), Mid-Term Evaluation of the EFA Fast Track Initiative Country Case Study: Nigeria, FTI-Nigeria Report Document, Abuja.

Socio-Economic Rights and Accountability Project (SERAP) (2013), Education fund embezzlement in Nigeria, available at: https://www.channelstv.com/tag/education-fund-embezzlement-innigeria/ (accessed: 22 November 2016).

Tayo, S.S, and Talabi, R.B. (2015), "Teacher shortage in Nigerian schools: Causes, effects and administrators coping strategies", Asia Pacific Journal of Education, Arts and Sciences, vol. 2 no. 4, pp. 31-37.

Tayo, S.S. (2013), Strengthening the Institutional Management of Education for Quality Service Delivery: Lagos State Experiment. Being a paper presented at the $5^{\text {th }}$ Quadrennial Nigeria Union of Teachers $\left(16^{\text {th }}\right)$ State Delegate Conference, Ikorodu, Lagos.

The Guardian (2014), Global teacher shortage threatens progress on education, available at: https:/www.theguardian.com/global-development/datablog/2011/oct/07/un-estimate-teachersshortage-worldwide (accessed: 23 March 2018).

Tiamiyu, R.A. (2012), "Questioning the claim of inadequate funding of tertiary education in Oyo State, Nigeria", International Journal of Governmental Financial Management, vol. 2, no. 4, pp. 46-61.

UNDP (2010), Nigeria Human Development Report, OUP, New York.

UNESCO/EFA (2009), Global Monitoring Report, UNESCO, Paris.

UNICEF/Nigeria (2010), Primary School Pupils in Class, available at: http://www.unicef.org/ Nigeria/children-1937.html (accessed: 23 March 2018).

World Bank (2008), World Bank / DFID Education Sector Public Expenditure Review, World Bank, Abuja. 